CASE REPORT

\title{
Incidental Lingual Thyroid: A Case Report and Review of Literature
}

\author{
Veerasigamani Narendrakumar ${ }^{1}$, Geethalakshmi Sampathkumar $^{2}$
}

\begin{abstract}
The presence of the thyroid gland outside its compartment is defined as ectopic thyroid. It is an abnormal embryological development. When present in the base of the tongue, it is lingual thyroid. We report this case of incidental lingual thyroid during routine clinical examination and highlight the importance of endoscopic examination in otorhinolaryngology.

Keywords: Hypothyroidism, Lingual thyroid, Videolaryngoscopy.

Otorhinolaryngology Clinics: An International Journal (2020): 10.5005/jp-journals-10003-1349
\end{abstract}

\section{INTRODUCTION}

Ectopic thyroid is characterized by the presence of thyroid tissue other than its normal position. It was first described by Hickman in 1869. ${ }^{1}$ Its prevalence rates vary with 1 in 100,000 to 1 in 300,000 and incidence is 1:100,000. It is seven times higher in females. ${ }^{2}$ Ectopic thyroid gland is due to an embryologic anomaly, which occurs in the process of thyroid migration and development. The thyroid gland is derived from an endodermal thickening in the floor of the primitive pharynx. It arises between the first and second branchial arches, which develops on the 24th day of intrauterine life. Initially, it is localized at the boundary between the body and the base of the tongue. By the 7th week of intrauterine life, the thyroid cord forms the thyroglossal duct, and it descends becoming solid tissue, localized at the height of the embryologic laryngeal-tracheal skeleton. $^{3}$

\section{Case Description}

A 37-year-old male came to our outpatient department with complaints of throat pain, belching, and occasional difficultly in swallowing for the past 6 months. He was diagnosed and treated for gastroesophageal reflux disease for a longer duration by a physician elsewhere. On ENT examination, ear and nose were normal and on videolaryngoscopy, showed small smooth reddish swelling of $1 \mathrm{~cm}$ diameter attached to the base of the tongue (Fig. 1), which was not visualized duration routine throat examination. Computerized tomography scan of the neck showed lingual thyroid with no thyroid gland in the pretracheal region (Fig. 2). Thyroid function test showed hypothyroidism TSH-23.17 $\mu \mathrm{lU} / \mathrm{ml}(0.45-4.5)$, T3-103.9 ng/dl (70-204), and T4-6.20 $\mu \mathrm{gm} / \mathrm{dl}$ (4.87-11.72). He was started on levothyroxine at the dose of $100 \mu \mathrm{g} /$ day. After a follow-up of 3 months, he was symptomatically improved and repeat thyroid function tests were normal.

\section{Discussion}

Lingual thyroids are of four groups, and they are lingual, sublingual, thyroglossal, and intralaryngeal. ${ }^{4}$ Pathogenesis remains unknown. Suggestions define that maternal antibodies may arrest the descent of thyroid tissue and that the incidence of this disease among family members can be higher if compared to the general population. ${ }^{5}$
${ }^{1}$ Pragathi ENT Clinic, Chennai, Tamil Nadu, India

${ }^{2}$ Pragathi Endocrine Clinic, Chennai, Tamil Nadu, India

Corresponding Author: Veerasigamani Narendrakumar, Pragathi ENT Clinic, Chennai, Tamil Nadu, India, Phone: +91 9080250830, e-mail: drnarenkapv@yahoo.com

How to cite this article: Narendrakumar V, Sampathkumar G. Incidental Lingual Thyroid: A Case Report and Review of Literature. Int J Otorhinolaryngol Clin 2020;12(2):25-26.

Source of support: Nil

Conflict of interest: None

The mutational genes responsible for thyroid migration are Nkx 2-1, Nkx 2-5, PAX8, and Foxe1. ' Symptoms may vary depending upon the lingual thyroid size. They are dysphagia, dysphonia, cough, and snoring. ${ }^{6}$ Rapid dimensional increase of ectopic tissue during hypermetabolic conditions, such as, pregnancy, infections, trauma, and menopause, is helpful in diagnosis. ${ }^{3}$ CT scan of the neck will demonstrate the lingual thyroid in axial and sagittal planes. ${ }^{7}$ On MRI, lingual thyroid tissue is seen as iso- or hypointense to the tongue

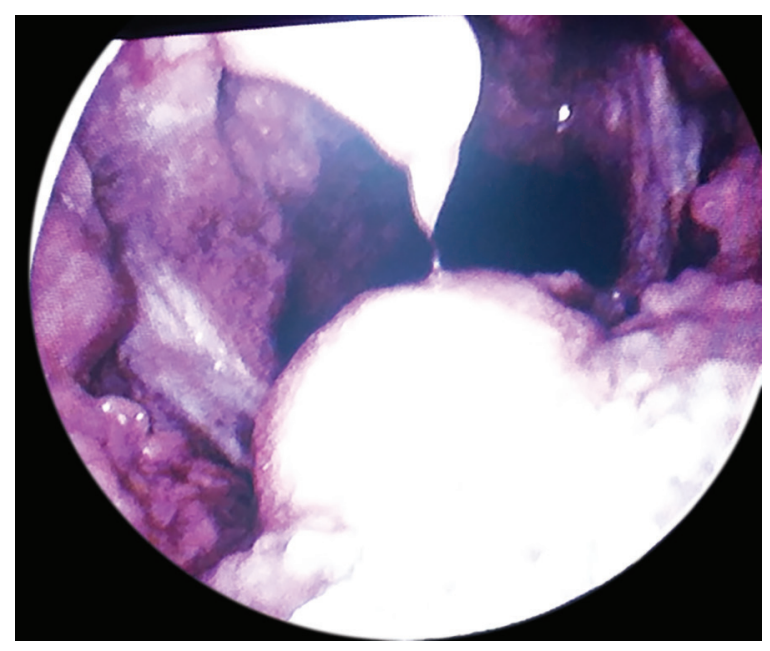

Fig. 1: Videolaryngoscopy picture showing lingual thyroid

( ) Jaypee Brothers Medical Publishers. 2020 Open Access This article is distributed under the terms of the Creative Commons Attribution 4.0 International License (https://creativecommons.org/licenses/by-nc/4.0/), which permits unrestricted use, distribution, and non-commercial reproduction in any medium, provided you give appropriate credit to the original author(s) and the source, provide a link to the Creative Commons license, and indicate if changes were made. The Creative Commons Public Domain Dedication waiver (http://creativecommons.org/publicdomain/zero/1.0/) applies to the data made available in this article, unless otherwise stated. 

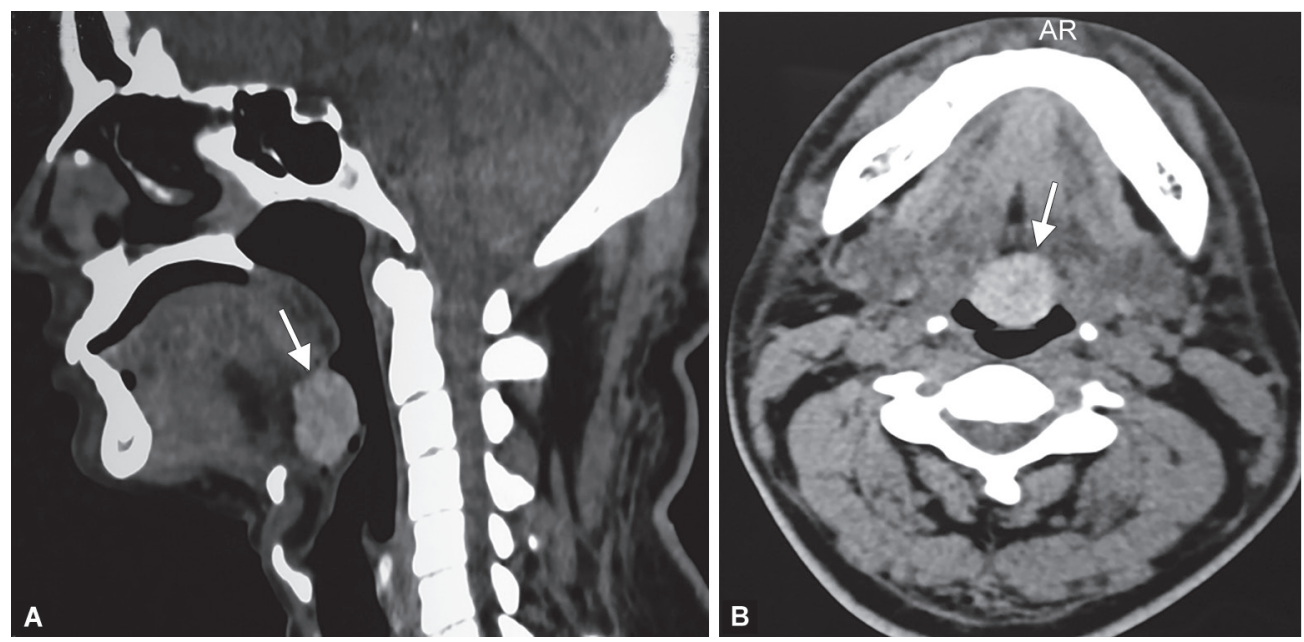

Fig. 2A and B: (A) CT scan of the neck-sagittal cut; (B) CT scan of the neck-axial cut showing lingual thyroid

muscles in T1-weighted sequences and more hyperintense than the tongue muscles in $\mathrm{T} 2 .^{8}$

Branchial cleft cysts, lingual thyroglossal cyst, metastatic thyroid carcinoma, lymphatic malformations, dermoid cysts and epidermoid cysts, lingual abscesses, and squamous cell carcinoma of the base of the tongue are few differential diagnosis. ${ }^{3}$ The case highlights the importance of presurgical evaluation of the broader medical history and the role of multidisciplinary communication. ${ }^{9}$

Medical treatment is hormone replacement therapy with thyroxine, which aims both to restore thyroid function and to avoid the development of ectopic tissue to prevent surgery. ${ }^{10}$ Surgical excision is the treatment for lingual thyroid, but it should be attempted until radioactive isotope scan has determined that there is an adequate thyroid tissue in the neck. In patients lacking thyroid tissue in the neck, lingual thyroid can be excised and autotransplanted to the muscles of the neck. ${ }^{11}$

Many surgical approaches are described, such as, transoral route, transhyoid route, suprahyoid, and lateral pharyngotomy, in which transoral route is the preferred approach avoiding deeper structures complications, such as, lingual nerve injury and deep cervical infections. $^{12}$

Lingual thyroid presence should be considered in all patients with a midline area of radioiodine uptake at the level of the chin, especially if it is approx resistant to radioiodine ablation. ${ }^{13}$

\section{ConCLUSION}

In general, ectopic lingual thyroid must be taken into consideration as a differential diagnosis when a mass lesion is observed in the tongue base even incidentally, and it must be verified using ultrasonography, scintigraphy, and CT and MRI scans. Treatment protocol depends upon the symptomatology. ${ }^{8}$ This case is reported due to the advantage of endoscopy and treatment of incidental lingual thyroid.

\section{References}

1. Amani ME, Benabadji N, Benzian Z, et al. Ectopic lingual thyroid. Indian J Nucl Med 2012;27(2):124-126. DOI: 10.4103/0972-3919.110718.

2. Amr B, Monib S. Lingual thyroid: a case report. Int J Surg Case Rep 2011;2(8):313-315. DOI: 10.1016/j.ijscr.2011.10.004.

3. Fiaschetti V, Claroni G, Scarano AL, et al. Diagnostic evaluation of a case of lingual thyroid ectopia. Radiol Case Rep 2016 Jun 1;11(3):165170. DOI: 10.1016/j.radcr.2016.04.004.

4. Chiu TT, Su C, Hwang CY, et al. Massive bleeding from an ectopic lingual thyroid follicular adenoma during pregnancy. Am J Otolaryngol 2002;23(3):185-188. DOI: 10.1053/ajot.2002.123432.

5. Stoppa-Vaucher S, Lapointe A, Turpin S, et al. Ectopic thyroid gland causing dysphonia: imaging and molecular studies. J Clin Endocrinol Metab 2010;95(10):4509-4510. DOI: 10.1210/jc.2010-0882.

6. Chanin LR, Greenberg LM. Pediatric upper airway obstruction due to ectopic thyroid: classification and case reports. Laryngoscope 1988;98(4):422-427. DOI: 10.1288/00005537-198804000-00014.

7. Gleeson M. Scott-Brown's otorhinolaryngology, Head and neck surgery, 7th edition. Great Britain: Edward Arnold Publishing Ltd; 2008.

8. Khamassi K, Jaafoura H, Masmoudi F, et al. Ectopic Lingual Thyroid. Case Rep Pediatr 2015;(1):1-4. DOI: 10.1155/2015/252357.

9. Goode A, McKellar C, Carter M, et al. Incidental lingual thyroid informs surgery. J Nucl Med Technol 2015;43(1):66-67. DOI: 10.2967/ jnmt.114.142075.

10. Noussios G, Anagnostis P, Goulis DG, et al. Ectopic thyroid tissue: anatomical, clinical, and surgical implications of a rare entity. Eur $J$ Endocrinol 2011;165(3):375-382. DOI: 10.1530/EJE-11-0461.

11. Kumar SS, Muthiah Selva Kumar D, Thirunavukuarasu R. Lingual thyroid-conservative management or surgery? A case report. Indian J Surg 2013;75(1):118-119. DOI: 10.1007/s12262-012-0518-4.

12. Bode Rovena, Agolli Medi, Celiku Etmond. Lingual thyroid gland: a case report. J Dent Med Sci 2015;14(8):73-77. DOI: 10.9790/085314887377.

13. Basaria S, Westra W, Cooper D. Ectopic Lingual Thyroid Masquerading as Thyroid Cancer Metastases. J Clin Endocrinol Metab 2001;86(1):392395. DOI: 10.1210/jcem.86.1.7130. 